\title{
Pregled teorijskih okvira i suvremenih pristupa za poticanje konceptualnog i proceduralnog znanja u matematici
}

\author{
Vanja Putarek \\ Sveučilište u Zagrebu, Filozofski fakultet u Zagrebu, Odsjek za psihologiju, Hrvatska
}

\begin{abstract}
Sažetak
Matematika je jedno od ključnih obrazovnih područja, a stjecanje matematičkih kompetencija ima dalekosežne učinke na akademski i profesionalni razvoj pojedinaca. Osnovni su aspekti matematičkih kompetencija konceptualno znanje, koje predstavlja razumijevanje pojmova, i proceduralno znanje, koje se odnosi na primjenu postupaka s ciljem rješavanja zadataka. Obje su vrste znanja važne za razvoj adaptivne stručnosti i uspjeh u matematici. Kako bi se kroz obrazovni proces potaknulo stjecanje konceptualnog i proceduralnog znanja, korisno je načine poučavanja oblikovati u skladu s pristupima koji su se pokazali učinkovitima u istraživanjima i praksi. Stoga je jedan cilj ovoga rada bio prikazati osnovne teorijske okvire o poučavanju matematike tijekom 20. stoljeća, kao i dva recentna pristupa koja su proizašla iz trenutno dominantnoga teorijskog okvira, konstruktivizma - korištenje usporedbi i produktivna pogreška. Kod usporedbe učenici jedan postupak rješavanja zadataka uspoređuju s novim postupkom, a kroz tu usporedbu mogu uočiti ključna obilježja postupaka koja ih ujedno i razlikuju. U odnosu na sekvencijalni način prikazivanja postupaka korištenje se usporedbi pokazuje djelotvornijim za stjecanje proceduralnog znanja i fleksibilnosti te konceptualnog znanja. Produktivna se pogreška temelji na integraciji metoda vođenog otkrivanja i izravnog poučavanja te se provodi u dvije faze: 1) učenici samostalno ili u grupi otkrivaju rješenja zadataka; 2) kroz poučavanje od strane učitelja uspoređuju svoja rješenja s točnim rješenjima, što dovodi do otkrivanja i ispravljanja negativnog znanja te razumijevanja osnovnih pojmova u određenom gradivu. Usprkos pozitivnim učincima ovom su pristupu upućene kritike, o kojima se govori u ovome radu. Na temelju je prikazanih informacija drugi cilj rada bio odrediti smjernice za praksu i buduća istraživanja kako bi se povećao broj učenika s razvijenim matematičkim kompetencijama koje su važne za uključivanje učenika u globalno sve traženija STEM zanimanja.
\end{abstract}

Ključne riječi: matematičke kompetencije, konceptualno i proceduralno znanje, usporedba, produktivna pogreška

Vanja Putarek, Odsjek za psihologiju, Filozofski fakultet Sveučilišta u Zagrebu, Ivana Lučića 3, 10000 Zagreb, Hrvatska. E-pošta: vputarek@ffzg.hr 


\section{Uvod}

Matematičke se kompetencije temelje na razvoju i povezivanju razumijevanja matematičkih pojmova ili postupaka te vještine rješavanja zadataka (Silver, 1986). Iako razumijevanje sadržaja ima značajan doprinos uspješnosti u matematici, tijekom povijesti se, ali i u suvremenom društvu, naglasak često stavlja na uvježbavanje postupka rješavanja zadataka (Verschaffel, Luwel, Torbeyns i Van Dooren, 2009). Primjerice, učitelj pokazuje postupak rješavanja nekog zadatka nakon čega učenici primjenjuju tu strategiju na ostalim zadacima (Posamentier i Krulik, 1998). Ovakvim se poučavanjem potiče rutinska stručnost (Hatano, 2003). Točnije, imitiranjem nastavnikovih rješenja učenici brzo i točno rješavaju poznate zadatke, ali bez razumijevanja, zbog čega su neuspješni u nestandardnim i novim zadacima (Harskamp i Suhre, 2007).

Stoga je jedan od najvažnijih obrazovnih ciljeva poticanje adaptivne stručnosti kod učenika, čime bi učenici bili kompetentni primijeniti stečena znanja na fleksibilan način (Hatano, 2003). Adaptivni stručnjaci, za razliku od rutinskih, mogu verbalizirati principe koji su u osnovi različitih postupaka i procijeniti njihovu prikladnost te modificirati ili stvoriti nove postupke ovisno o zahtjevima situacije (Hatano i Inagaki, 1986). Oni lakše i učinkovitije uče u novim situacijama te manje primjenjuju sheme koje su prethodno bile korisne, ali nisu učinkovite u novoj situaciji (Hatano i Oura, 2003; Wineburg, 1998). Drugim riječima, adaptivni su stručnjaci usvojili osnovne aspekte matematičkih kompetencija: razumijevanje matematičkih pojmova ili postupaka i vještinu rješavanja zadataka. Ova se dva aspekta matematičkih kompetencija nazivaju konceptualno i proceduralno znanje te su temeljito proučavani od 1980-ih godina (Hiebert i LeFevre, 1986).

U početku su se istraživači usmjerili na odnos između konceptualnog i proceduralnog znanja te na relativnu važnost jednog oblika znanja u odnosu na drugi, dok u posljednja dva desetljeća intenzivnije istražuju načine poticanja ovih dvaju oblika znanja. Potreba je za daljnjim razvojem ovog područja i dalje prisutna, s naglaskom na mogućnost primjene postojećih spoznaja u praksi. Naime, uspjeh $u$ matematici prediktor je uspjeha na fakultetu i kasnijih financijskih prihoda (Rose i Betts, 2001), a predviđa i kompetencije iz drugih školskih predmeta, poput razumijevanja teksta (Lerkkanen, Rasku-Puttonen, Aunola i Nurmi, 2005). Iz navedenog se može zaključiti da je razvoj učinkovitih pristupa poučavanju matematičkih kompetencija važan, ne samo za poboljšanje ishoda poučavanja u području matematike već i za ukupno obrazovno postignuće učenika. Stoga je cilj ovog rada dvojak. S jedne strane, cilj je prikazati dosadašnje spoznaje o pristupima poučavanju koji potiču stjecanje konceptualnog i proceduralnog znanja. S druge strane, sukladno prikazanim informacijama, cilj je rada odrediti implikacije dosadašnjih istraživanja za praksu i smjernice za buduća istraživanja. 


\section{Konceptualno i proceduralno znanje}

Konceptualno znanje definira se kao općenito i apstraktno znanje o osnovnim načelima ili pojmovima u nekom području te o međusobnim odnosima tih načela ili pojmova. Ova vrsta znanja pohranjena je u obliku relacijskih reprezentacija, poput shema i semantičkih mreža (Hiebert i LeFevre, 1986), i dostupna je za fleksibilne transformacije (Baroody i Dowker, 2003). Konceptualno znanje može biti eksplicitno i implicitno, pa ga nije moguće uvijek verbalizirati (Rittle-Johnson i Alibali, 1999; Rittle-Johnson i Schneider, 2015). Kod konceptualnog su znanja veze između informacija podjednako važne kao i same informacije (Rittle-Johnson i Schneider, 2015). Konačno, konceptualno znanje nije vezano uz specifični sadržaj i obuhvaća znanje o sadržajno različitim pojmovima te njihovim odnosima. Stoga se smatra da je konceptualno znanje višedimenzionalni konstrukt.

Proceduralno znanje predstavlja znanje o različitim postupcima koji se primjenjuju kako bi se postigao neki cilj (Byrnes i Wasik, 1991; Rittle-Johnson, Siegler i Alibali, 2001). Dok konceptualno znanje znači da osoba "zna nešto" (engl. knowing that), proceduralno znanje znači da osoba "zna kako" (engl. knowing how). Ovisno o količini vježbe proceduralno je znanje automatizirano do određenog stupnja, a kod veće automatizacije koristi se uz minimalni svjesni napor i malo ulaganja kognitivnih resursa, što može negativno djelovati na stupanj fleksibilnosti (Johnson, 2003). Budući da je djelomično automatizirano i svjesno, proceduralno se znanje teško verbalizira ili transformira od strane viših kognitivnih procesa. Posljedično, često je vezano uz specifične vrste problema na kojima je to znanje usvojeno (Rittle-Johnson, Siegler i Alibali, 2001; Rittle-Johnson, Schneider i Star, 2015). Međutim, proceduralno znanje može biti i dubinski obrađeno i fleksibilno te može uključivati znanje o primjeni različitih postupaka u odgovarajućim uvjetima, što se naziva proceduralna fleksibilnost (Star, 2005).

\section{Odnos između konceptualnog i proceduralnog znanja}

Za teoretičare i praktičare u ovom području važna pitanja koja se postavljaju su redoslijed javljanja i uzročno-posljedični odnos između konceptualnog i proceduralnog znanja. Kao odgovori definirane su četiri perspektive i za svaku od njih postoje istraživanja koja ih podupiru.

Prema prvoj se perspektivi najprije razvija konceptualno znanje, i to neformalnim iskustvom s numeričkim pojmovima, a zatim se, iskustvom rješavanja različitih zadataka, razvija proceduralno znanje (Byrnes, 1992; Gelman i Meck, 1983; Hiebert i Wearne, 1986). Suprotno tome, druga perspektiva pretpostavlja da se najprije razvija proceduralno znanje, na temelju pokušaja i pogrešaka u rješavanju zadataka u neformalnom okruženju, a iz proceduralnog se znanja procesom apstrakcije generiraju pojmovi (Alibali i Goldin-Meadow, 1993; Briars i Siegler, 1984; Siegler i Stern, 1998). Prema trećoj perspektivi, nazvanoj perspektiva 
inaktivacije (Haapasalo i Kadijevich, 2000), konceptualno i proceduralno znanje razvijaju se nezavisno (Resnick, 1982; Resnick i Omanson, 1987).

Prema danas najprihvaćenijoj, iterativnoj perspektivi odnos je između konceptualnog i proceduralnog znanja dvosmjeran, odnosno povećanjem jedne vrste znanja dolazi do povećanja druge vrste znanja (Baroody, 2003; Rittle-Johnson i Siegler, 1998; Rittle-Johnson i sur., 2001). Pretpostavlja se da će se ovisno o izloženosti djeteta pojmovima ili postupcima u okolini u većoj mjeri najprije razviti konceptualno ili proceduralno znanje (Rittle-Johnson i Siegler, 1998). Početno znanje može biti prvenstveno konceptualno ako je dijete u neformalnom ili školskom okruženju izloženo pojmovima više nego postupcima. Suprotno tome, ako je dijete u većoj mjeri izloženo postupcima rješavanja zadataka, početno će znanje biti proceduralno. Početni je razvoj jedne od ovih dviju vrsta znanja praćen razvojem druge vrste znanja.

Međutim, $u$ istraživanjima je dobiveno da iterativan odnos ne postoji kod svih učenika te da međusobni utjecaj jedne vrste znanja na drugu nije podjednak. Prvo, prema istraživanju Hallett, Nunes i Bryanta (2010) postoje klasteri učenika ovisno o tome koliko se oslanjaju na ove dvije vrste znanja: 1) učenici koji se oslanjaju na proceduralno znanje; 2) učenici koji se oslanjaju na konceptualno znanje; 3) učenici koji se podjednako i u velikoj mjeri oslanjaju na obje vrste znanja; 4) učenici koji imaju nisko razvijeno konceptualno ili proceduralno znanje, bez kompenziranja drugom vrstom znanja. Dakle, važno je uzeti u obzir individualne razlike prilikom razmatranja odnosa između konceptualnog i proceduralnog znanja.

Drugo, rezultati pojedinih istraživanja pokazuju da konceptualno znanje ima veći utjecaj na proceduralno znanje nego obrnuto (Hecht i Vagi, 2010; Matthews i Rittle-Johnson, 2009; Rittle-Johnson i Alibali, 1999). Drugim riječima, poticanjem uvježbavanja postupaka u manjoj će se mjeri potaknuti razumijevanje pojmova i načela koji su u pozadini rješavanja zadataka, dok će se poticanjem razumijevanja u većoj mjeri razviti i proceduralno znanje tijekom uvježbavanja postupaka.

\section{Teorijski okviri i pristupi za poticanje konceptualnog i proceduralnog znanja}

\section{Teorijski okviri za poučavanje konceptualnog i proceduralnog znanja}

Budući da su konceptualno i proceduralno znanje osnovni aspekti matematičkih kompetencija, njihovo je poticanje sastavni dio različitih teorija o učinkovitim načinima poučavanja matematike. Promjenama se dominantnih paradigmi $u$ psihologiji općenito mijenjala i usmjerenost na pojedinu vrstu znanja u poučavanju matematike.

U prvoj su se polovici 20. stoljeća dominantni pristupi poučavanju matematike temeljili na biheviorističkoj paradigmi (Schoenfeld, 1987, 2008). Tako se, prema 
asocijacionistima, učenje odvija prema principima klasičnog uvjetovanja te je ključno ponavljanje informacija i uvježbavanje postupaka (engl. drill and practice) kako bi se uspostavile veze između okoline (npr. pitanje ili zadatak) i odgovora (npr. točan odgovor na pitanje ili točno rješavanje zadatka). Može se zaključiti da su asocijacionisti bili usmjereni na usvajanje proceduralnog znanja, odnosno na njegovu automatizaciju, dok su razumijevanje sadržaja stavljali u drugi plan ili je bilo potpuno zanemareno. Usmjerenost je na proceduralno znanje bila prisutna i sredinom 20. stoljeća, kada se dominantan pogled na učenje temeljio na instrumentalnom uvjetovanju. Točnije, učenici su poučavani preko potkrepljivanja točnih reakcija i kroz oblikovanje ponašanja u okviru programiranih materijala, a cilj je bilo učenje bez pogrešaka (Resnick, 1983; Schoenfeld, 2008). Dakle, u okviru bi biheviorističkog pristupa poučavanju matematike učitelji trebali osigurati uvjete za uvježbavanje postupaka i potkrepljivati točne odgovore.

Suprotno tome, kognitivizam, koji je postao dominantna paradigma krajem 1950-ih godina, stavlja naglasak na procese obrade informacija, poput primanja, pohrane i dosjećanja informacija te načina povećanja učinkovitosti tih procesa (Ertmer i Newby, 2013; Resnick i Ford, 1981). Prema kognitivistima učenici su aktivno uključeni u proces učenja te rabe različite strategije učenja kako bi organizirali nove informacije u postojeće kognitivne sheme. Važno je da učenici uvježbaju postupke rješavanja zadataka, ali bi se to poznavanje postupaka trebalo temeljiti na njihovu razumijevanju. Dakle, osim proceduralnog znanja kognitivizam uzima u obzir i konceptualno znanje te pretpostavlja da konceptualno znanje treba prethoditi proceduralnom znanju.

Slično tome, konstruktivizam, koji predstavlja dominantan teorijski okvir u protekla tri desetljeća, uzima u obzir i učenika i okolinu te aktivnu ulogu učenika tijekom učenja, ali ističe važnost vlastitih interpretacija informacija i mogućnost smislene primjene znanja u određenom kontekstu (Jonassen, 1991). Učitelji bi trebali pružati različite perspektive na pojedine informacije ili zadatke, uvažavati pogreške kao sastavni dio učenja, poticati učenike na suradničko učenje i primjenu znanja. Dakle, konstruktivisti su, kao i kognitivisti, u većoj mjeri usmjereni na konceptualno nego na proceduralno znanje prilikom poučavanja matematike.

Može se primijetiti da je tijekom 20. stoljeća u teorijama o poučavanju matematike smanjena usmjerenost na proceduralno znanje, a povećana usmjerenost na konceptualno znanje. Nadalje, od isključivog naglašavanja samo jedne vrste znanja i rutinske stručnosti za vrijeme biheviorističke paradigme kognitivizam i konstruktivizam pomaknuli su se prema uvažavanju obje vrste znanja i adaptivne stručnosti. Također, u skladu $\mathrm{s}$ istraživanjima o uzročno-posljedičnom odnosu između konceptualnog i proceduralnog znanja veći se naglasak stavlja na konceptualno znanje.

Unutar tri navedena teorijska okvira razvijeni su različiti pristupi poučavanju matematike. Tako su u skladu s konstruktivizmom razvijena dva suvremena pristupa koje su se pokazali osobito učinkovitima za razvoj konceptualnog, ali i 
proceduralnog znanja: korištenje usporedbi (engl. contrasted comparison; comparing solution methods or problems) i produktivna pogreška (engl. productive failure).

\section{Korištenje usporedbi}

Uspoređivanje zadataka, primjera ili situacija osnovni je princip učenja koji potiče dubinsko razumijevanje podražajnog materijala (Gentner, 2005). Laboratorijska su istraživanja pokazala da uspoređivanje dva primjera u većoj mjeri pospješuje učenje nego proučavanje jednog primjera ili proučavanje dva primjera nezavisno jednog o drugome (Loewenstein i Gentner, 2001; Namy i Gentner, 2002; Silver, Ghousseini, Gosen, Charalambous i Strawhun, 2005). Primjerice, uspoređivanje pozitivno pridonosi učenju riječi kod djece (Gentner i Namy, 2004) ili učenju strategija pregovaranja kod studenata (Gentner, Loewenstein i Thompson, 2003).

Opažanjem je rada nastavnika u zemljama u kojima učenici imaju vrlo visoko znanje iz matematike (npr. Japan, Hong Kong) uočeno da nastavnici u tim zemljama potiču učenike na generiranje različitih postupaka za rješavanje zadatka, raspravu o tim postupcima i njihovu usporedbu (Stigler i Hiebert, 1999). Dakle, usporedba je postupaka i zadataka sastavni dio poučavanja matematike u ovim obrazovnim sustavima, što je sugeriralo da uspoređivanje djeluje kao učinkovit način učenja i u matematici.

Stoga su provedena istraživanja kako bi se u prirodnim uvjetima provjerila učinkovitost uspoređivanja postupaka i zadataka u odnosu na druge strategije i pristupe. Pritom su istraživači, osim rezultata prethodno navedenih laboratorijskih istraživanja (npr. Gentner i sur., 2003), uzeli u obzir i rezultate istraživanja iz područja psihologije obrazovanja. Točnije, usmjerili su se na važnost proučavanja riješenih primjera za dubinsko razumijevanje sadržaja, kao i korištenje zadataka za uvježbavanje naučenih postupaka (Atkinson, Derry, Renkl i Wortham, 2000) te korisnost učenja s drugim učenikom iz razrednog odjeljenja s kojim učenik može izmijeniti i provjeriti svoje ideje (Fuchs i sur., 1997; Webb, 1991).

Sukladno tome, nacrti istraživanja najčešće su u prvom koraku sadržavali proučavanje riješenih primjera, a u drugom rješavanje nekoliko zadataka, pri čemu je svaki učenik prolazio kroz oba koraka zajedno s drugim učenikom (Rittle-Johnson, 2017; Rittle-Johnson i Star, 2007, 2009; Star i Rittle-Johnson, 2009). Istraživanja su provedena u prirodnim uvjetima te su učitelji matematike koji poučavaju u razrednim odjeljenjima uključenima $\mathrm{u}$ istraživanje sami primjenjivali ispitivane pristupe. Primjerice, u istraživanju Rittle-Johnson i Star (2007) učenici (12 - 13 godina) prvi su dan riješili predtest $u$ kojem su ispitani proceduralno znanje i fleksibilnost te konceptualno znanje. Na kraju tog sata učitelj bi ukratko objasnio osnovne principe rješavanja linearnih jednadžbi jer bi to bio prvi susret učenika s tim gradivom. Potom bi sljedeća dva dana učenici proučavali primjere i rješavali zadatke u paru, dok bi 
posljednji, četvrti dan, riješili posttest koji je ispitivao iste matematičke kompetencije kao i predtest, a učitelj bi sumirao sve informacije o rješavanju linearnih jednadžbi. Manipulacija se načinom poučavanja sastojala u prikazivanju riješenih primjera. Naime, neki bi parovi dobili riješene primjere prikazane sekvencijalno, odnosno imali bi prikazana dva ekvivalentna zadatka jedan nakon drugoga te bi jedan zadatak bio riješen standardnim postupkom rješavanja linearnih jednadžbi, a drugi zadatak učinkovitijim postupkom. Ostali su učenici u razredu imali prikazan jedan zadatak riješen istim standardnim postupkom te odmah desno pored njega isti zadatak riješen učinkovitijim postupkom. Pored koraka su kod oba postupka bili navedeni nazivi računskih operacija ili postupaka koji su provedeni te su učenici trebali odgovarati na nekoliko pitanja o riješenim primjerima (Prilog 1.). Dobiveno je da je usporedba različitih postupaka rješavanja zadataka učinkovitija za poticanje konceptualnog $\mathrm{i}$ proceduralnog znanja, mjereno učinkom na posttestu, u odnosu na sekvencijalno prikazivanje riješenih primjera. Može se primijetiti da su prethodno opisani koraci usporedbe u skladu s konstruktivizmom (npr. uvažavanje socijalnog konteksta i suradničkog učenja, prethodnog znanja učenika i sposobnosti konstrukcije znanja).

Dodatno su istraživanja pokazala da prethodno opisano uspoređivanje istog zadatka riješenog različitim postupcima (engl. comparing solution methods) u većoj mjeri potiče konceptualno i proceduralno znanje u odnosu na uspoređivanje ekvivalentnih zadataka riješenih istim postupkom, dok u odnosu na uspoređivanje različitih zadataka riješenih istim postupkom u većoj mjeri potiče samo konceptualno, ali ne i proceduralno znanje (Rittle-Johnson i Star, 2009). Osim toga, isti je učinak usporedbe na konceptualno i proceduralno znanje dobiven i kada su učenici učili individualno, ne u parovima (Ziegler i Stern, 2016).

Učinkovitost uspoređivanja načina rješavanja zadataka ovisi o početnoj razini znanja učenika. Kod početnika u nekom području može doći do pada u konceptualnom i proceduralnom znanju nakon izlaganja usporedbi jer je njihovo radno pamćenje opterećeno velikim brojem informacija (npr. proučavanje dvaju nepoznatih postupaka rješavanja zadataka i njihova usporedba) (Rittle-Johnson, Star i Durkin, 2009). Kod učenika koji usvoje jedan postupak rješavanja zadataka dolazi do porasta u proceduralnom i konceptualnom znanju, pa je preporučljivo da učenici najprije razumiju i uvježbaju jedan postupak, a tek nakon toga uspoređuju taj postupak s nekim novim postupkom.

\section{Produktivna pogreška}

Osnovno su polazište za pristup produktivne pogreške i metoda izravnog poučavanja i metoda vođenog otkrivanja (Kapur i Toh, 2013). Izravno je poučavanje najčešći oblik poučavanja u školama (Roelofs, Visser i Terwel, 2003), kod kojeg se kombiniraju tehnike izlaganja i uvježbavanja, odnosno učenici najprije dobivaju od učitelja strukturirane informacije, a zatim uvježbavaju postupke za sadržaje za koje je to potrebno (Wise i O'Neill, 2009). Međutim, suvremene reforme obrazovanja 
stavljaju veći naglasak na poučavanje vođenim otkrivanjem, koje se temelji na prethodno opisanom konstruktivizmu (Loveless, 1998). Nadalje, produktivna pogreška uzima u obzir istraživanja važnosti pripreme za učenje kroz otkrivanje rješenja zadataka prije poučavanja (engl. inventing solutions; problem-solving), kao i istraživanja o važnosti pogrešaka tijekom učenja (Kapur, 2015a).

\section{Otkrivanje rješenja zadataka prije poučavanja}

Tradicija istraživanja učenja utemeljenog na otkrivanju rješenja zadataka bez poučavanja ili prije njega stara je nekoliko desetljeća i obuhvaća različita obrazovna područja, ali je velik dio istraživanja proveden u području medicine i na uzorku nadarenih učenika (Hmelo-Silver, 2004). Pristupi u okviru ove tradicije imaju različite nazive, poput učenje na temelju problema (engl. problem-based learning) te iskustveno ili konstruktivističko učenje (Kirschner, Sweller i Clark, 2006), a svima je zajedničko generiranje rješenja za neki sadržaj prije poučavanja o tom sadržaju, što je u skladu s načelima konstruktivizma o važnosti i prirodi prethodnog znanja učenika.

Kod učenja na temelju problema učenici ili studenti u grupi rješavaju složene probleme, odnosno zadatke na koje u pravilu nema jednoga točnog odgovora kako bi postali intrinzično motivirani konstruktori vlastita znanja (Hmelo-Silver, 2004). Pritom se često upotrebljava konstruktivistička tehnika građenja skela kako bi učenici ili studenti uz određene smjernice mogli doći do rješenja zadataka (Lazonder i Harmsen, 2016; Schmidt, Loyens, Van Gog i Paas, 2007). Dakle, poučavanje ne prethodi rješavanju zadataka, već učenici ili studenti uz vođeno otkrivanje dolaze do njihova rješenja. Učitelji imaju važnu ulogu u usmjeravanju pažnje učenika na ključne pojmove, težeći pritom ostvarivanju dvaju ciljeva: 1) uspješno rješavanje zadataka; 2) učenje novih pojmova i postupaka koje bi trebalo dovesti do dugotrajnijeg upamćivanja te dubljeg razumijevanja sadržaja (Kapur, 2016). Iz tog razloga Kapur (2016) ovaj pristup naziva produktivnim uspjehom, za razliku od učenja koje se temelji isključivo na izravnom poučavanju, koje naziva neproduktivnim uspjehom jer dovodi samo do kratkotrajnog učenja.

Otkrivanje se rješenja zadataka može integrirati s poučavanjem od strane učitelja tako da učitelj najprije traži od učenika da rješavaju zadatke i pokušavaju doći do rješenja, a nakon toga ih poučava pojmovima i postupcima rješavanja zadataka iz tog gradiva. Velik dio istraživanja o učinkovitosti ovakvog načina poučavanja govori u prilog važnosti otkrivanja rješenja zadataka, kao i analize zadataka ili nekoga tekstualnog sadržaja prije poučavanja, za učinkovito učenje (DeCaro i Rittle-Johnson, 2012; Schwartz i Bransford, 1998; Schwartz, Chase, Oppezzo i Chin, 2011; Schwartz i Martin, 2004). Osobito se korisnim pokazala primjena usporedbe primjera tijekom faze otkrivanja rješenja (Roll, Aleven i Koedinger, 2009, 2011). Naime, kada učenici analiziraju dva zadatka, ili više njih, 
koji se razlikuju u nekom ključnom obilježju, spremniji su uočiti i razumjeti definirajuća obilježja pojmova i samostalno riješiti zadatke.

Osim otkrivanja rješenja zadataka prije poučavanja može se primijeniti i tzv. problem-posing, koji uključuje reformuliranje ili proširenje zadatka te generiranje novih zadataka u određenoj situaciji (Silver, 1994). U istraživanju Kapura (2015b) problem-posing operacionaliziran je kao generiranje pitanja ili zadataka na temelju prikazanog primjera i podataka. Uspoređujući dvije situacije, 1) generiranje pitanja na temelju prikazanog primjera prije poučavanja i 2) generiranje rješenja na temelju zadanog zadatka prije poučavanja, pokazalo se da generiranje rješenja dovodi do većeg uspjeha na mjerama konceptualnog znanja u odnosu na generiranje pitanja, dok generiranje pitanja dovodi do boljeg transfera. Pretpostavlja se da generiranje rješenja dovodi do aktivacije postojećeg znanja koje je u većoj mjeri kontingentno traženim pojmovima, dok generiranje pitanja potiče aktivaciju šire baze znanja i fleksibilno rezoniranje.

\section{Važnost pogrešaka tijekom učenja}

Pogreške su kao dio učenja uklopljene u konstruktivistički pristup, što izvire iz teorija na kojima se temelji taj pristup, poput Piagetove kognitivne teorije, teorija konceptualne promjene i sociokulturne teorije Vygotskog (Kapur, 2015a). Istraživanja o učenju na temelju zastoja (engl. impasse-driven learning) također govore o važnosti pogrešaka tijekom učenja. Zastoj, koji predstavlja oblik pogreške prilikom učenja, javlja se kada osoba nema dovoljno znanja da postigne neki cilj ili ima dovoljno znanja, ali ne može odrediti koji bi način bio optimalan za postizanje cilja (VanLehn, 1999). Tako studenti koji nailaze na zastoj prilikom rješavanja zadataka pokazuju bolje razumijevanje pojmova tijekom poučavanja i kasnijeg rješavanja zadataka u odnosu na studente koji ne nailaze na zastoj (VanLehn, Siler, Murray, Yamauchi i Baggett, 2003). Dakle, ako studenti sami pokušavaju doći do rješenja i kasnije kroz poučavanje uoče miskoncepcije, učenje će biti kvalitetnije nego kada učitelji pružaju rješenja i ignoriraju pogreške kao nepoželjni dio procesa učenja.

Istraživanje Mathana i Koedingera (2003) o vremenu davanja povratne informacije također je pružilo rezultate koji podržavaju shvaćanje o važnosti pogrešaka prilikom učenja. Točnije, učenici kojima su učitelji ispravljali pogreške s većom odgodom brže su naučili gradivo i dugoročnije ga upamtili te su postizali veći transfer u odnosu na učenike kojima je učitelj odmah ispravljao pogreške, ne ostavljajući prostora za učenje iz tih pogrešaka. Moguće je da odgođena povratna informacija manje opterećuje kapacitet radnog pamćenja u odnosu na povratnu informaciju koja se daje odmah nakon što se učini pogreška, omogućujući time uočavanje pogrešaka i samokorekciju (Schooler i Anderson, 1990). Međutim, potrebno je uzeti u obzir i prethodno znanje učenika jer učenici s manje znanja više profitiraju od povratnih informacija koje uslijede odmah nakon izvedbe, dok takve 
povratne informacije imaju negativan učinak na konceptualno i proceduralno znanje učenika koji već posjeduju osnovna znanja o nekom sadržaju (Fyfe i Rittle-Johnson, 2016).

\section{Istraživanja o učinkovitosti produktivne pogreške}

Produktivna se pogreška provodi u dvije faze: učenici u prvoj fazi samostalno pokušavaju riješiti zadatke i/ili doći do razumijevanja koncepata, a potom u drugoj fazi kroz raspravu s učiteljem i drugim učenicima te poučavanje od strane učitelja dolaze do boljeg razumijevanja sadržaja (Kapur i Bielaczyc, 2012). Za razliku od prethodno opisanih istraživanja o učinkovitosti otkrivanja rješenja zadataka prije poučavanja u kojima su korišteni jednostavniji primjeri koji se razlikuju po jednom ključnom obilježju kod produktivne su pogreške zadaci bogati informacijama i primjeri se razlikuju prema većem broju obilježja kako bi se aktivirala što veća baza znanja kod učenika i što raznolikija rješenja (Loibl i Rummel, 2014). Dakle, važno je da pojedinci ili grupe generiraju što više rješenja kako bi učinkovitost ovog pristupa bila veća (tzv. efekt generiranja rješenja) (Kapur, 2015a).

U osnovi su produktivne pogreške četiri međusobno povezana mehanizma koji omogućuju nadilaženje nedostataka izravnog poučavanja (Kapur, 2015a). Prvo, kroz produktivnu se pogrešku aktivira početno znanje učenika koje može rezultirati netočnim ili nedovoljno kvalitetnim rješenjima koja se uspoređuju s točnim i optimalnim pojmovima ili postupcima tijekom druge faze. Drugo, učenici su usmjereni na ključne pojmove ili aspekte postupaka upravo zbog aktivacije početnog znanja (DeCaro i Rittle-Johnson, 2012; Kapur, 2014, 2016; Kapur i Bielaczyc, 2012). Treće, tijekom poučavanja objašnjavaju se i elaboriraju pojmovi, te četvrto, u konačnici se pojmovi organiziraju i integriraju u cjelinu (Kapur, 2015a). Dakle, iako je otkrivanje rješenja zadataka prije poučavanja kognitivno zahtjevno, to otkrivanje dovodi do pozitivnih učinaka tijekom i nakon učenja.

Istraživanja su potvrdila učinkovitost produktivne pogreške za stjecanje matematičkih kompetencija, osobito za stjecanje konceptualnog znanja (Kapur, 2015a). Primjerice, Kapur (2014) je ispitivao djelovanje redoslijeda rješavanja zadataka i poučavanja o standardnoj devijaciji kod učenika od 14 i 15 godina. Učenici koji su najprije individualno rješavali zadatke prema principima produktivne pogreške, a potom su bili poučavani o standardnoj devijaciji imali su bolje konceptualno znanje od učenika koji su najprije bili poučavani, a zatim su rješavali zadatke. Pritom se u ovom istraživanju poučavanje temeljilo na prethodno opisanoj usporedbi različitih načina rješavanja zadataka, odnosno učitelj je uspoređivao pojmove i postupke kroz četiri primjera. Osim toga, učenici koji su najprije rješavali zadatke imali su bolje rezultate na mjerama konceptualnog znanja i u odnosu na učenike koji su najprije samo proučavali tuđe primjere riješenih zadataka, a zatim su bili poučavani o standardnoj devijaciji. Učenici koji su najprije rješavali zadatke iskazivali su na mjerama samoprocjene veće ulaganje truda i izraženiji kognitivni 
napor u odnosu na druge skupine učenika te su generirali veći broj rješenja nego učenici koji su zadatke rješavali nakon poučavanja.

Istraživanja o produktivnoj pogrešci u kojima su korištene grupe, a ne individualno rješavanje zadataka (Kapur, 2012; Kapur i Bielaczyc, 2012; Kapur, Dickson i Toh, 2008), kao i poučavanje u okviru obrnute učionice (engl. flipped classrooms; samostalno proučavanje gradiva kod kuće i interaktivna nastava $\mathrm{s}$ rješavanjem zadataka u školi) (Song i Kapur, 2017) dobiveni su rezultati kao i u prethodno opisanim istraživanjima. Također, kod učenika nižih i viših matematičkih sposobnosti dobiven je podjednak doprinos produktivne pogreške u odnosu na izravno poučavanje, pa se može zaključiti da učenici različitih matematičkih sposobnosti profitiraju od poučavanja pomoću produktivne pogreške (Kapur i Bielaczyc, 2012).

Važno je napomenuti da se prednost produktivne pogreške u odnosu na izravno poučavanje dobiva i u slučaju da se posttest primjenjuje odmah nakon što se primijene oba pristupa (npr. Kapur, 2014) i u slučaju da se primjenjuje naknadno (npr. dan nakon primjene pristupa; Kapur, 2012). Drugim riječima, iako su učenici izloženi produktivnoj pogrešci bili poučavani u drugoj fazi, odnosno kasnije $u$ odnosu na grupu koja je izložena izravnom poučavanju, prednost se produktivne pogreške ne može pripisati efektu recentnosti (Kapur, 2014). Nadalje, čak i kada učitelj tijekom poučavanja usmjerava pažnju učenika na osnovna obilježja pojmova, samo je poučavanje o tim obilježjima manje učinkovito od otkrivanja tih obilježja (Kapur i Bielaczyc, 2011).

U istraživanju je Kapura (2011) produktivna pogreška, kod koje učenici ne dobivaju pomoć od učitelja za vrijeme početnog rješavanja zadataka, bila učinkovitija u odnosu na metodu vođenog rješavanja zadataka, kod koje učenici dobivaju smjernice od učitelja za vrijeme početnog rješavanja zadataka. Pokazalo se da su učenici izloženi vođenom rješavanju zadataka bili uspješni u rješavanju zadataka, ali su na posttestu učenici izloženi produktivnoj pogrešci bili uspješniji na mjerama proceduralnog i konceptualnog znanja te transfera.

\section{Preporuke za primjenu produktivne pogreške}

Kako bi produktivna pogreška bila učinkovita, prilikom njezina korištenja zadaci trebaju biti dovoljno izazovni kako bi se učenici uključili u rješavanje, ali ne previše izazovni kako ne bi odustali od rješavanja (Kapur, 2016). Nadalje, zadaci trebaju poticati generiranje različitih postupaka, rješenja i reprezentacija, pružajući mogućnosti za otkrivanje rješenja. Zadaci bi trebali aktivirati početno, formalno i intuitivno, znanje učenika, ali je važno da to znanje bude kontingentno sadržajima koji će se poučavati (Glogger-Frey, Fleischer, Grüny, Kappich i Renkl, 2015). Pritom nije važno da rješenja budu točna, već da se kroz generiranje rješenja i aktivaciju početnog znanja učenici pripreme za učenje (Kapur, 2016). 
Učinkovitost produktivne pogreške ovisi i o procesu samostalnog građenja skela za vrijeme prve faze, odnosno za vrijeme početnog traženja rješenja (Collins, 2012). U tom je procesu korisno metakognitivno građenje skela i primjena usporedbe primjera (Roll, Holmes, Day i Bonn, 2012). Točnije, učenici bi trebali uspoređivati primjere i na temelju te usporedbe pokušati doći do rješenja. Pritom se dodatno koristi samoobjašnjavanje kod kojeg učenici sami sebi objašnjavaju i argumentiraju rješenja, te uspoređivanje vlastita rješenja s onim od drugih učenika.

Nadalje, $u$ drugoj fazi primjene produktivne pogreške, dakle $u$ fazi poučavanja, učinkovitost ovog pristupa povećavaju primjeri, traženje samoobjašnjavanja i sustavna refleksija informacija (Collins, 2012). Također, važno je da učitelji uspoređuju rješenja koja su učenici generirali tijekom prve faze s optimalnim ili kanoničkim postupcima i rješenjima (Loibl i Rummel, 2014). Kroz ovu usporedbu učitelji upućuju na ograničenja postojećeg znanja učenika (Glogger-Frey, Fleischer i sur., 2015). Drugim riječima, učenici postanu svjesni negativnog znanja ili znanja o tome koja rješenja nisu djelotvorna i zašto (Oser, Näpflin, Hofer i Aerni, 2012). Stoga je povratna informacija od strane učitelja izuzetno važna za stjecanje znanja i razumijevanje pojmova te je ona jedan od ključnih elemenata učinkovite primjene produktivne pogreške (Glogger-Frey, Fleischer i sur., 2015).

Konačno, važno je uzeti u obzir zonu približnog razvoja učenika kako traženje rješenja ne bi bio prelagan ili pretežak, a time i nemotivirajući zadatak za učenike (Collins, 2012).

\section{Kritike korištenju otkrivanja rješenja zadataka prije poučavanja}

Iako otkrivanje rješenja prije poučavanja i produktivna pogreška rezultiraju boljim razumijevanjem sadržaja, upućene su i kritike ovim načinima poučavanja (Colliver, 2000). Tako se pretpostavlja da učenici kroz otkrivanje rješenja zadataka prije poučavanja mogu doći do pogrešnih rješenja koja ih onda vode do pogrešnog razumijevanja pojmova. Naime, ljudi više vrednuju proizvode koje sami naprave, tzv. efekt IKEA (Norton, Mochon i Ariely, 2012), pa učenici rješenja koja sami generiraju vrednuju više nego rješenja koja im kasnije pokazuju učitelji, odnosno eksperti, i teže asimiliraju njihova rješenja u svoje sheme (Glogger-Frey, Fleischer, i sur., 2015).

Nadalje, prema teoriji kognitivnog opterećenja otkrivanje rješenja zadataka prije poučavanja predstavlja opterećenje za resurse radnog pamćenja zbog kojeg se ono ne može uključiti u pohranjivanje informacija u dugoročno pamćenje (Kirschner i sur., 2006; Sweller, Kirschner i Clark, 2007).

Jedan je od načina smanjivanja kognitivnog opterećenja koje izaziva otkrivanje rješenja analiziranje riješenih primjera prije poučavanja (Tuovinen i Sweller, 1999). Tako su u istraživanju Glogger-Frey, Fleischer i suradnika (2015) studenti i učenici od 13 i 14 godina postizali bolje rezultate na zadacima transfera ako su proučavali riješene primjere prije poučavanja prikazane prethodno opisanom usporedbom 
različitih načina rješavanja zadataka, u odnosu na otkrivanje rješenja zadataka, također, prije poučavanja. Međutim, u istraživanju je Glogger-Frey, Kappich i suradnika (2015) grupa izložena otkrivanju rješenja zadataka prije poučavanja, u kontekstu učenja pomoću računala, postizala bolje rezultate na mjerama procesa učenja i transfera u odnosu na kontrolnu skupinu koja je učila na temelju čitanja riješenih primjera.

Dakle, rezultati istraživanja o učinkovitosti proučavanja riješenih primjera su nekonzistentni, što se može bolje razumjeti ako se uzme u obzir početna razina znanja sudionika istraživanja. Tako studenti početnici u području postižu bolje rezultate na testovima ako uče iz analiziranih primjera nego ako otkrivaju rješenja, ali povećanjem znanja u području otkrivanje rješenja zadataka prije poučavanja postaje učinkovitije u odnosu na proučavanje riješenih primjera (Kalyuga, Chandler, Sweller i Tuovinen, 2001).

Osim toga, kao odgovor pristalicama teorije kognitivnog opterećenja Kapur (2016) navodi da veće kognitivno opterećenje nije nužno negativno za proces učenja. Naime, veće kognitivno opterećenje može dovesti do usmjeravanja pažnje na važna obilježja zadatka i do aktivacije prijašnjeg znanja koje posljedično rezultira boljim povezivanjem postojećeg i novog znanja. Osim toga, aktivacija prijašnjeg znanja može osloboditi kapacitete radnog pamćenja, pa se time i smanjuje opterećenje radnog pamćenja (Kapur, 2015a).

Kritičari učenja na temelju problema navode i da postoje metodološki nedostaci provedenih istraživanja, poput nepostojanja ili nedovoljno dobre usporedne grupe (Kirschner i sur., 2006; Sweller i sur., 2007), što može rezultirati i nekonzistentnostima u rezultatima istraživanjima. Naime, rezultati pojedinih istraživanja ne potvrđuju veće učinke otkrivanja rješenja zadataka prije poučavanja na stjecanje znanja u odnosu na izravno poučavanje. Primjerice, Capon i Kuhn (2004) su na uzorku studenata poslovne škole dobili rezultate koji pokazuju da nema razlike u stjecanju znanja i dosjećanju između studenta koji su poučavani pomoću učenja na temelju problema i onih koji su poučavani o ključnim pojmovima i njihovim primjerima. Međutim, važno je napomenuti da je učenje na temelju problema pokazalo veći učinak na integraciju informacija nego učenje utemeljeno samo na izravnom poučavanju. Dakle, potrebno je provoditi daljnja istraživanja u prirodnim uvjetima, uz metodološka poboljšanja, kako bi se provjerili rezultati, ali i proširile postojeće spoznaje o učenju na temelju problema i produktivnoj pogrešci.

\section{Praktične implikacije i smjernice za buduća istraživanja}

$\mathrm{Na}$ temelju se pregleda teorijskih okvira te suvremenih pristupa za što učinkovitije stjecanje matematičkih kompetencija može uočiti trend sve većeg poticanja razumijevanja i pojmova i procedura, uvažavanja postojećeg znanja učenika te suradničkog učenja. Navedeni trend u skladu je s konstruktivizmom te 
spoznajama o uzročno-posljedičnom odnosu konceptualnog i proceduralnog znanja. Iako u obrazovnim politikama i istraživanjima konstruktivizam dominira kao pristup već nekoliko desetljeća, u velikom je broju obrazovnih sustava u praksi i dalje naglasak na rutinskoj stručnosti (Verschaffel i sur., 2009).

Sukladno se prikazanim spoznajama o korištenju usporedbe i produktivnoj pogrešci može zaključiti da bi se primjenom ovih pristupa učenici približili adaptivnoj stručnosti u matematici jer bi informacije koje obrađuju bile kvalitetnije procesirane, a time bi i mogućnost primjene tako stečenih znanja bila veća. Stoga se može preporučiti poučavanje barem dijela kurikula u području matematike u skladu $\mathrm{s}$ konstruktivističkim načelima sadržanima u usporedbi i produktivnoj pogrešci. Točnije, učitelji bi trebali u obzir uzeti prethodnu razinu znanja učenika, omogućiti početno rješavanje računskih i problemskih zadataka prije poučavanja novog gradiva koje je djelomično potrebno za rješavanje i razumijevanje tih zadataka, tražiti višestruke načine (postupke) rješavanja nekog zadatka, na temelju pogrešaka učenika pokušati razumjeti kakva je priroda znanja učenika te poticati suradničko učenje.

Kako bi se to moglo postići, u obrazovanje učitelja treba inkorporirati konstruktivistička načela. Naime, u Hrvatskoj više učitelja predmetne nastave i nastavnika u srednjoj školi navodi da se slaže s pristupom usmjerenim na nastavu (npr. kompetitivnost, prijenos činjeničnih informacija kroz izravno poučavanje), s kojim su se i sami više susretali tijekom obrazovanja, nego s pristupom usmjerenim na učenika (npr. korištenje tehnike rasprave, sudjelovanje učenika u ocjenjivanju vlastitog napretka) (Vizek Vidović, 2005). Rezultati PISA istraživanja također sugeriraju prevladavanje prijenosa, a ne konstrukcije znanja u hrvatskom obrazovnom sustavu (Braš Roth, Markočić Dekanić i Markuš Sandrić, 2017). Stoga je važno već u obrazovanju učitelja upućivati na korisnost prethodno opisanog konstruktivizma, kao i na fleksibilnost u primjeni pojedinih metoda, pristupa ili strategija s obzirom na sadržaj.

$\mathrm{Na}$ temelju se prikazanih rezultata istraživanja o usporedbi i produktivnoj pogrešci može zaključiti da konstruktivizam daje adekvatan okvir za poticanje matematičkih kompetencija, ali je potrebno proširiti postojeća istraživanja u nekoliko smjerova.

Prvo, postavlja se pitanje kako dva prethodno opisana pristupa djeluju na motivacijske procese. U kontekstu je otkrivanja rješenja zadatka prije poučavanja dobiveno da ono ima pozitivan učinak na stvaranje situacijskog interesa i epistemičke znatiželje (Glogger-Frey, Kappich i sur., 2015; Norman i Schmidt, 1992), kao i na stvaranje ciljeva ovladavanja uključivanjem (Belenky i NokesMalacha, 2012). Dakle, može se pretpostaviti da bi i produktivna pogreška, kao i usporedba, mogle pozitivno djelovati na interes i ciljeve postignuća učenika, ali je potrebno provesti istraživanja kojima će se to provjeriti.

Osim toga, važno je ispitati kakva je samoefikasnost učenika u matematici nakon učenja pomoću navedenih pristupa. Naime, samoefikasnost u matematici prediktor je odabira STEM područja kao studijskog programa (Wang, 2013), a 
upravo je povećanje broja pojedinaca obrazovanih u STEM području goruća tema obrazovnih politika diljem svijeta. Manjak broja zaposlenih u STEM zanimanjima povezan je sa slabijim ekonomskim razvitkom države te zbog tehnološkog razvitka potreba za zaposlenima u STEM području raste (Caprile, Palmén, Sanz i Dente, 2015). Stoga je važno već kroz osnovnu školu potaknuti motivaciju učenika za odabirom STEM zanimanja te razviti matematičke kompetencije potrebne za snalaženje u tim zanimanjima. Dakle, iako usporedba i produktivna pogreška pružaju obećavajuće nalaze po pitanju poticanja matematičkih kompetencija, važno je ispitati i njihovo djelovanje na motivacijske procese, kako bi se djelujući i na njih povećao broj zaposlenih u STEM područjima.

Drugo, potrebno je provesti istraživanja kojima će se provjeriti prikladnost primjene usporedbe i produktivne pogreške $\mathrm{s}$ obzirom na različite vrste sadržaja te $\mathrm{s}$ obzirom na individualne razlike u obilježjima učenika. Naime, do sada su navedeni pristupi u pravilu istraživani u područjima rješavanja jednadžbi i statistike. Postavlja se pitanje djeluju li ovi pristupi na matematičke kompetencije i u području geometrije ili drugim specifičnim temama unutar algebre ili statistike. Nadalje, pojedini učenici izloženi poučavanju produktivnom pogreškom pokazuju veći napredak u odnosu na učenike izložene izravnom poučavanju, dok drugi učenici pokazuju manji napredak (Kapur, 2015a). Buduća bi istraživanja trebala odgovoriti na pitanje dolazi li do navedenih razlika zbog obilježja učenika (npr. dob, razina stručnosti i/ili motivacije, osobine poput potrebe za spoznajom) i/ili obilježja interakcijskog procesa između učitelja i učenika.

Treće, potrebno je provesti longitudinalna istraživanja kojima će se provjeriti koliko su dugotrajni kognitivni, ali i potencijalni motivacijski učinci ovih pristupa te koji sve čimbenici djeluju na smanjenje ili održavanje tih učinaka.

Četvrto, potrebno je uzeti u obzir valjanost mjera konceptualnog i proceduralnog znanja. Uobičajene su mjere konceptualnog znanja definiranje i objašnjavanje pojmova ili postupaka te zadaci transfera ili rješavanje nepoznatih zadataka (Rittle Johnson i Schneider, 2015; Siegler i Stern, 1998; Vamvakoussi i Vosniadou, 2004). Proceduralno se znanje obično mjeri preko točnosti postupka ili rješenja, a ponekad i preko vremena rješavanja zadataka (Canobi, 2004; Rittle Johnson i Schneider, 2015). Međutim, nijedna od ovih mjera nema zadovoljavajuća psihometrijska svojstva (Rittle Johnson i Schneider, 2015). U prilog tome govori i istraživanje Schneidera i Stern (2010) u kojem su četiri mjere konceptualnog znanja, kao i četiri mjere proceduralnog znanja, imale nisku konvergentnu valjanost. Samo je za jednu mjeru konceptualnog znanja dobiveno da se povećala u grupi koja je bila izložena konceptualnoj intervenciji i za jednu mjeru proceduralnog znanja da se povećala u grupi koja je bila izložena proceduralnoj intervenciji. Dakle, ovisno o tome koja se mjera uzima u obzir dobivaju se različiti rezultati. Također, mjerenje konceptualnog znanja zahvaća i proceduralno znanje, i obrnuto, stoga je potrebno istražiti koje su mjere dobri pokazatelji konceptualnog i proceduralnog znanja te koristiti višemetodski pristup, a ne izdvojene, pojedinačne mjere. 


\section{Zaključak}

Konceptualno i proceduralno znanje, kao osnovni aspekti matematičkih kompetencija, razvijaju se kroz neformalno, ali prvenstveno kroz formalno iskustvo i obrazovanje. Stoga je važno kroz prikladne pristupe potaknuti kod učenika upravo ova dva oblika znanja, kako bi postali adaptivni stručnjaci, bez straha od matematike i sa slikom o sebi kao kompetentnom matematičaru/matematičarki. Dva su pristupa utemeljena na konstruktivizmu, koji su se pokazali učinkovitima za poticanje konceptualnog i proceduralnog znanja, usporedba, osobito usporedba različitih načina rješavanja zadataka, i produktivna pogreška. Kod primjene obaju pristupa dolazi do dubljeg procesiranja informacija kod učenika i transfera na nepoznate sadržaje. Dodatnim je istraživanjima potrebno provjeriti dugoročne učinke ovih pristupa, primijeniti ih na različite nastavne sadržaje te ispitati njihov odnos $\mathrm{s}$ motivacijskim i socijalnim procesima u razrednom odjeljenju.

\section{Literatura}

Alibali, M. W. i Goldin-Meadow, S. (1993). Gesture-speech mismatch and mechanisms of learning: What the hands reveal about a child's state of mind. Cognitive Psychology, 25(4), 468-573. doi:10.1006/cogp.1993.1012

Atkinson, R. K., Derry, S. J., Renkl, A. i Wortham, D. (2000). Learning from examples: Instructional principles from the worked examples research. Review of Educational Research, 70(2), 181-214. doi:10.3102/00346543070002181

Baroody, A. J. (2003). The development of adaptive expertise and flexibility: The integration of conceptual and procedural knowledge. U: A. J. Baroody i A. Dowker (Ur.), The development of arithmetic concepts and skills: Constructing adaptive expertise (str. 133). Mahwah, NJ: Erlbaum.

Baroody, A. J. i Dowker, A. (2003). Preface. U: A. J. Baroody i A. Dowker (Ur.), The development of arithmetic concepts and skills: Constructing adaptive expertise (str. 1521). Mahwah. NJ: Erlbaum.

Belenky, D. M. i Nokes-Malach, T. J. (2012). Motivation and transfer: The role of masteryapproach goals in preparation for future learning. Journal of the Learning Sciences, 21(3), 399-432. doi:10.1080/10508406.2011.651232

Braš Roth, M., Markočić Dekanić, A. i Markuš Sandrić, M. (2017). PISA 2015: Prirodoslovne kompetencije za život. Zagreb: Nacionalni centar za vanjsko vrednovanje obrazovanja.

Briars, D. J. i Siegler, R. S. (1984). A featural analysis of preschoolers' counting knowledge. Developmental Psychology, 20(4), 607-618. doi:10.1037/0012-1649.20.4.607

Byrnes, J. P. (1992). The conceptual basis of procedural learning. Cognitive Development, 7(2), 235-237. doi:10.1016/0885-2014(92)90013-H 
Byrnes, J. P. i Wasik, B. A. (1991). Role of conceptual knowledge in mathematical procedural learning. Developmental Psychology, 27(5), 777-786. doi:10.1037//0012-1649.27.5. 777

Canobi, K. H. (2004). Individual differences in children's addition and subtraction knowledge. Cognitive Development, 19(1), 81-93. doi:10.1016/j.cogdev.2003.10.001

Capon, N. i Kuhn, D. (2004). What's so good about problem-based learning? Cognition and Instruction, 22(1), 61-79. doi.10.1207/s1532690Xci2201_3

Caprile, M., Palmén, R., Sanz, P. i Dente, G. (2015). Encouraging STEM studies: Labour market situation and comparison of practices targeted at young people in different member states. Policy Department A: Economic and Scientific Policy; European Parliament. Preuzeto s http://www.europarl.europa.eu/RegData/etudes/STUD/2015/ 542199/IPOL_STU(2015)542199_EN.pdf.

Collins, A. (2012). What is the most effective way to teach problem solving? A commentary on productive failure as a method of teaching. Instructional Science, 40(4), 731-735. doi:10.1007/s11251-012-9234-5

Colliver, J. (2000). Effectiveness of problem-based learning curricula: Research and theory. Academic Medicine, 75(3), 259-266. doi:10.1097/00001888-200003000-00017

DeCaro, M. S. i Rittle-Johnson, B. (2012). Exploring mathematics problems prepares children to learn from instruction. Journal of Experimental Child Psychology, 113(4), 552-568. doi:10.1016/j.jecp.2012.06.009

Ertmer, P. A. i Newby, T. J. (2013). Behaviorism, cognitivism, constructivism: Comparing critical features from an instructional design perspective. Performance Improvement Quarterly, 26(2), 43-71. doi:10.1002/piq.21143

Fuchs, L. S., Fuchs, D., Hamlett, C. L., Phillips, N. B., Karns, K. i Dutka, S. (1997). Enhancing students' helping behavior during peer-mediated instruction with conceptual mathematical explanations. The Elementary School Journal, 97(3), 223-249. doi:10.1086/461863

Fyfe, E. R. i Rittle-Johnson, B. (2016). Feedback both helps and hinders learning: The causal role of prior knowledge. Journal of Educational Psychology, 108(1), 82-97.

Gelman, R. i Meck, E. (1983). Preschoolers' counting: Principles before skill. Cognition, 13(3), 343-359. doi:10.1016/0010-0277(83)90014-8

Gentner, D. (2005). The development of relational category knowledge. U: D. H. Rakison i L. Gershkoff-Stowe (Ur.), Building object categories in developmental time (str. 245275). Mahwah, NJ: Erlbaum.

Gentner, D., Loewenstein, J. i Thompson, L. (2003). Learning and transfer: A general role for analogical encoding. Journal of Educational Psychology, 95(2), 393-405. doi:10.1037/ 0022-0663.95.2.393

Gentner, D. i Namy, L. L. (2004). The role of comparison in children's early word learning. U: S. R. Waxman i D. G. Hall (Ur.), Weaving a lexicon (str. 533-568). Cambridge, MA: MIT Press. 
Glogger-Frey, I., Fleischer, C., Grüny, L., Kappich, J. i Renkl, A. (2015). Inventing a solution and studying a worked solution prepare differently for learning from direct instruction. Learning and Instruction, 39, 72-87. doi:10.1016/j.learninstruc.2015.05.001

Glogger-Frey, I., Kappich, J., Schwonke, R., Holzäpfel, L., Nückles, M. i Renkl, A. (2015). Inventing motivates and prepares student teachers for computer-based learning. Journal of Computer Assisted Learning, 31(6), 546-561. doi:10.1111/jcal.12097

Haapasalo, L. i Kadijevich, D. (2000). Two types of mathematical knowledge and their relation. JMD-Journal for Mathematic-Didaktik, 21(2), 139-157. doi:10.1007/BF 03338914

Hallett, D., Nunes, T. i Bryant, P. (2010). Individual differences in conceptual and procedural knowledge when learning fractions. Journal of Educational Psychology, 102(2), 395406. doi:10.1037/a0017486

Harskamp, E. i Suhre, C. (2007). Schoenfeld's problem solving theory in a student controlled learning environment. Computers \& Education, 49(3), 822-839. doi:10.1016/j. compedu.2005.11.024

Hatano, G. (2003). Foreword. U: A. J. Baroody i A. Dowker (Ur.), The development of arithmetic concepts and skills (str. 11-13). Mahwah, NJ: Lawrence Erlbaum Associates.

Hatano, G. i Inagaki, K. (1986). Two courses of expertise. U: H. A. H. Stevenson i K. Hakuta (Ur.), Child development and education in Japan (str. 262-272). New York: Freeman.

Hatano, G. i Oura, Y. (2003). Commentary: Reconceptualizing school learning using insight from expertise research. Educational Researcher, 32(8), 26-29. doi:10.3102/0013189 X032008026

Hecht, S. A. i Vagi, K. J. (2010). Sources of group and individual differences in emerging fraction skills. Journal of Educational Psychology, 102(4), 843-859. doi:10.1037/ a0019824

Hiebert, J. i LeFevre, P. (1986). Conceptual and procedural knowledge in mathematics: An introductory analysis. U: J. Hiebert (Ur.), Conceptual and procedural knowledge: The case of mathematics (str. 1-28). Hillsdale, NJ: Erlbaum.

Hiebert, J. i Wearne, D. (1986). Procedures over concepts: The acquisition of decimal number knowledge. U: J. Hieben (Ur.), Conceptual and procedural knowledge: The case of mathematics (str. 199-223). Hillsdale, NJ: Lawrence Erlbaum Associates.

Hmelo-Silver, C. E. (2004). Problem-based learning: What and how do students learn? Educational Psychology Review, 16(3), 235-266. doi:1040-726X/04/0900-0235/0

Johnson, A. (2003). Procedural memory and skill acquisition. U: I. B. Weiner (Ur.), Handbook of psychology (Vol. 4, str. 499-523). Hoboken, NJ: Wiley.

Jonassen, D. H. (1991). Evaluating constructivistic learning. Educational Technology, 31(9), 28-33.

Kalyuga, S., Chandler, P. A., Sweller, J. i Tuovinen, J. (2001). When problem solving is superior to studying worked examples. Journal of Educational Psychology, 93(3), 579588. doi:10.1037/0022-0663.93.3.579 
Kapur, M. (2011). A further study of productive failure in mathematical problem solving: Unpacking the design components. Instructional Science, 39(4), 561-579. doi:10.1007/ s11251-010-9144-3

Kapur, M. (2012). Productive failure in learning the concept of variance. Instructional Science, 40(4), 651-672. doi:10.1007/s11251-012-9209-6

Kapur, M. (2014). Productive failure in learning math. Cognitive Science, 38(5), 1008-1022. doi:10.1111/cogs.12107

Kapur, M. (2015a). Learning from productive failure. Learning: Research and Practice, 1(1), 51-65. doi:10.1080/23735082.2015.1002195

Kapur, M. (2015b). The preparatory effects of problem solving versus problem posing on learning from instruction. Learning and Instruction, 39, 23-31. doi:10.1016/j. learninstruc.2015.05.004

Kapur, M. (2016). Examining productive failure, productive success, unproductive failure, and unproductive success in learning, Educational Psychologist, 51(2), 289-299. doi:10.1080/00461520.2016.1155457

Kapur, M. i Bielaczyc, K. (2011). Classroom-based experiments in productive failure. U: L. A. Carlson, C. Hölscher i T. F. Shipley (Ur.), Proceedings of the 33th Annual Conference of the Cognitive Science Society (str. 2812-2817). Austin, TX: Cognitive Science Society.

Kapur, M. i Bielaczyc, K. (2012). Designing for productive failure. The Journal of the Learning Sciences, 21(1), 45-83. doi:10.1080/10508406.2011.591717

Kapur, M., Dickson, L. i Toh, P. Y. (2008). Productive failure in mathematical problem solving. U: B. C. Love, K. McRae i V. M. Sloutsky (Ur.), Proceedings of the 30th Annual Conference of the Cognitive Science Society (str. 1717-1722). Austin, TX: Cognitive Science Society.

Kapur, M. i Toh, P. L. L. (2013). Productive failure: From an experimental effect to a learning design. U: T. Plomp i N. Nieveen (Ur.), Educational design research - Part B: Illustrative cases (str. 341-355). Enschede, the Netherlands: SLO.

Kirschner, P. A., Sweller, J. i Clark, R. (2006). Why minimal guidance during instruction does not work: An analysis of the failure of constructivist, discovery, problem-based, experiential and inquiry-based teaching. Educational Psychologist, 41(2), 75-86. doi:10.1207/s15326985ep4102_1

Lazonder, A. W. i Harmsen, R. (2016). Meta-analysis of inquiry-based learning: Effects of guidance. Review of Educational Research, 86(3), 681-718. doi:10.3102/ 0034654315627366

Lerkkanen, M-K., Rasku-Puttonen, H., Aunola, K. i Nurmi, J-E. (2005). Mathematical performance predicts progress in reading comprehension among 7-year olds. European Journal of Psychology of Education, 20(2), 121-137. doi:10.1007/BF03173503 
Loewenstein, J. i Gentner, D. (2001). Spatial mapping in preschoolers: Close comparisons facilitate far mappings. Journal of Cognition and Development, 2(2), 189-219. doi:10.1207/S15327647JCD0202_4

Loibl, K. i Rummel, N. (2014). Knowing what you don't know makes failure productive. Learning and Instruction, 34, 74-85. doi:10.1016/j.learninstruc.2014.08.004

Loveless, T. (1998). The use and misuse of research in educational reform. U: D. Ravitch (Ur.), Education policy (str. 285-286). Washington, DC: Brookings Institution Press.

Mathan, S. i Koedinger, K. R. (2003). Recasting the feedback debate: Benefits of tutoring error detection and correction skills. U: U. Hoppe, F. Verdejo i J. Kay (Ur.), Artificial intelligence in education: Shaping the future of learning through intelligent technologies, Proceedings of AI-ED Conference (str. 13-18). Amsterdam: IOS Press.

Matthews, P. G. i Rittle-Johnson, B. (2009). In pursuit of knowledge: Comparing selfexplanations, concepts, and procedures as pedagogical tools. Journal of Experimental Child Psychology, 104(1), 1-21. doi:10.1016/j.jecp.2008.08.004

Namy, L. L. i Gentner, D. (2002). Making a silk purse out of two sow's ears: Young children's use of comparison in category learning. Journal of Experimental Psychology: General, 131(1), 5-15. doi:10.1037//0096-3445.131.1.5

Norman, G. R. i Schmidt, H. G. (1992). The psychological basis of problem based learning: A review of the evidence. Academic Medicine, 67(9), 557-565. doi:10.1097/00001888199209000-00002

Norton, M. I., Mochon, D. i Ariely, D. (2012). The IKEA effect: When labor leads to love. Journal of Consumer Psychology, 22(3), 453-460. doi:10.1016/j.jcps.2011.08.002

Oser, F. K., Näpflin, C., Hofer, C. i Aerni, P. (2012). Towards a theory of negative knowledge (NK): Almost-mistakes as drivers of episodic memory amplification. U: J. Bauer i C. Harteis (Ur.), Professional and practice-based learning. Human fallibility (str. 53-70). Netherlands: Springer. http://dx.doi.org/10.1007/978-90-481-3941-5_4

Posamentier, A. S. i Krulik, S. (1998). Problem-solving strategies for efficient and elegant solutions. California: Corwin Press Inc.

Resnick, L. B. (1982). Syntax and semantics in learning to subtract. U: T. P. Carpenter, J. M. Moser i T. A. Romberg (Ur.), Addition \& subtraction: A cognitive perspective (str. 136155). Hillsdale, NJ: Erlbaum.

Resnick, L. B. (1983). Toward a cognitive theory of instruction. U: S. Paris, G. M. Olson i H. W. Stevenson (Ur.), Leaning and motivation in the classroom (str. 5-38). Hillsdale, New Jersey: Lawrence Erlbaum Associates, Inc.

Resnick, L. B. i Ford, W. W. (1981). The psychology of mathematics for instruction. Hillsdale, New Jersey: Lawrence Erlbaum Associates.

Resnick, L. B. i Omanson, S. F. (1987). Learning to understand arithmetic. U: R. Glaser (Ur.), Advances in instructional psychology (Vol. 3, str. 41-95). Hillsdale, NJ: Erlbaum.

Rittle-Johnson, B. (2017). Developing mathematics knowledge. Child Development Perspectives, 11(3), 184-190. doi:10.1111/cdep.12229 
Rittle-Johnson, B. i Alibali, M. W. (1999). Conceptual and procedural knowledge of mathematics: Does one lead to the other? Journal of Educational Psychology, 91(1), 175-189. doi:10.1037//0022-0663.91.1.175

Rittle-Johnson, B. i Schneider, M. (2015). Developing conceptual and procedural knowledge of mathematics. U: R. C. Kadosh i A. Dowker (Ur.), Oxford handbook of numerical cognition (str. 1102-1118). Oxford: Oxford University Press.

Rittle-Johnson, B., Schneider, M. i Star, J. R. (2015). Not a one-way street: Bidirectional relations between procedural and conceptual knowledge of mathematics. Educational Psychology Review, 27(4), 587-597. doi:10.1007/s10648-015-9302-x

Rittle-Johnson, B. i Siegler, R. S. (1998). The relation between conceptual and procedural knowledge in learning mathematics: A review. U: C. Donlan (Ur.), The development of mathematical skills (str. 75-110). London: Psychology Press.

Rittle-Johnson, B., Siegler, R. S. i Alibali, M. W. (2001). Developing conceptual understanding and procedural skill in mathematics: An iterative process. Journal of Educational Psychology, 93(2), 346-362. doi:10.1037/0022-0663.93.2.346

Rittle-Johnson, B. i Star, J. R. (2007). Does comparing solution methods facilitate conceptual and procedural knowledge? An experimental study on learning to solve equations. Journal of Educational Psychology, 99(3), 561-574. doi:10.1037/0022-0663.99.3.561

Rittle-Johnson, B. i Star, J. R. (2009). Compared with what? The effects of different comparisons on conceptual knowledge and procedural flexibility for equation solving. Journal of Educational Psychology, 101(3), 529-544. doi:10.1037/a0014224

Rittle-Johnson, B., Star, J. R. i Durkin, K. (2009). The importance of prior knowledge when comparing examples: Influences on conceptual and procedural knowledge of equation solving. Journal of Educational Psychology, 101(4), 836-852. doi:10.1037/a0016026

Roelofs, E., Visser, J. i Terwel, J. (2003). Preferences for various learning environments: Teachers' and parents' perceptions. Learning Environments Research, 6(1), 77-110. doi:10.1023/A:1022915910198

Roll, I., Aleven, V. i Koedinger, K. R. (2009). Helping students know 'further'-increasing the flexibility of students' knowledge using symbolic invention tasks. U: N. A. Taatgen i H. van Rijn (Ur.), Proceedings of the 31st Annual Conference of the Cognitive Science Society (str. 1169-1174). Austin: Cognitive Science Society.

Roll, I., Aleven, V. i Koedinger, K. R. (2011). Outcomes and mechanisms of transfer. U: L. Carlson, C. Hoelscher i T. Shipley (Ur.), Proceedings of the 33rd Annual Conference of the Cognitive Science Society (str. 2824-2829). Austin: Cognitive Science Society.

Roll, I., Holmes, N. G., Day, J. i Bonn, D. (2012). Evaluating metacognitive scaffolding in guided invention activities. Instructional Science, 40(4), 691-710. doi:10.1007/s11251012-9208-7

Rose, H. i Betts, J. R. (2001). Math matters: The links between high school curriculum, college graduation, and earnings. San Francisco, CA: Public Policy Institute of California. 
Schneider, M. i Stern, E. (2010). The developmental relations between conceptual and procedural knowledge: A multimethod approach. Developmental Psychology, 46(1), 178-192. doi:10.1037/a0016701

Schmidt, H. G., Loyens, S. M. M., Van Gog, T. i Paas, F. (2007). Problem-based learning is compatible with human cognitive architecture: Commentary on Kirschner, Sweller, and Clark (2006). Educational Psychologist, 42(2), 91-97. doi:10.1080/004615207012 63350

Schoenfeld, A. H. (1987). Cognitive science and mathematics education: An overview. U: A. H. Schoenfeld (Ur.), Cognitive science and mathematics education (str. 1-33). Hillsdale, New Jersey: Lawrence Erlbaum Associates, Inc.

Schoenfeld, A. H. (2008). Research methods in (mathematics) education. U: L. D. English (Ur.), Handbook of international research in mathematics education (str. 467-519). New York, NY: Taylor and Francis.

Schooler, L. J. i Anderson, J. R. (1990). The disruptive potential of immediate feedback. U: M. Piattelli (Ur.), Proceedings of the 12th Annual Conference of the Cognitive Science Society (str. 702-708). Hillsdale, NJ: Lawrence Erlbaum Associates.

Schwartz, D. L. i Bransford, J. D. (1998). A time for telling. Cognition and Instruction, 16(4), 475-522. doi:10.1207/s1532690xci1604_4

Schwartz, D. L., Chase, C. C., Oppezzo, M. A. i Chin, D. B. (2011). Practicing versus inventing with contrasting cases: The effects of telling first on learning and transfer. Journal of Educational Psychology, 103(4), 759-775. doi:10.1037/a0025140

Schwartz, D. L. i Martin, T. (2004). Inventing to prepare for future learning: The hidden efficiency of encouraging original student production in statistics instruction. Cognition and Instruction, 22(2), 129-184. doi:10.1207/s1532690xci2202_1

Siegler, R. S. i Stern, E. (1998). Conscious and unconscious strategy discoveries: A microgenetic analysis. Journal of Experimental Psychology: General, 127(4), 377-397. doi:10.1037/0096-3445.127.4.377

Silver, E. A. (1986). Using conceptual and procedural knowledge: A focus on relationships. U: J. Hiebert (Ur.), Conceptual and procedural knowledge: The case of mathematics (str. 181-198). Hillsdale, NJ: Erlbaum.

Silver, E. A. (1994). On mathematical problem posing. For the Learning of Mathematics, 14(1), 19-28.

Silver, E. A., Ghousseini, H., Gosen, D., Charalambous, C. i Strawhun, B. (2005). Moving from rhetoric to praxis: Issues faced by teachers in having students consider multiple solutions for problems in the mathematics classroom. Journal of Mathematical Behavior, 24(3-4), 287-301. doi:10.1016/j.jmathb.2005.09.009

Song, Y. i Kapur, M. (2017). How to flip the classroom - "productive failure or traditional flipped classroom". Pedagogical design? Educational Technology \& Society, 20(1), 292-305. 
Star, J. R. (2005). Reconceptualizing procedural knowledge. Journal for Research in Mathematics Education, 36(5), 404-411.

Star, J. R. i Rittle-Johnson, B. (2009). It pays to compare: An experimental study on computational estimation. Journal of Experimental Child Psychology, 102(4), 408-426. doi:10.1016/j.jecp.2008.11.004

Stigler, J. W. i Hiebert, J. (1999). The teaching gap: Best ideas from the world's teachers for improving education in the classroom. New York, NY: The Free Press.

Sweller, J., Kirschner, P. A. i Clark, R. (2007). Why minimally guided teaching techniques do not work: A reply to commentaries. Educational Psychologist, 42(2), 115-121. doi:10.1080/00461520701263426

Tuovinen, J. E. i Sweller, J. (1999). A comparison of cognitive load associated with discovery learning and worked examples. Journal of Educational Psychology, 91(2), 334-341. doi:10.1037/0022-0663.91.2.334

Vamvakoussi, X. i Vosniadou, S. (2004). Understanding the structure of the set of rational numbers: A conceptual change approach. Learning and Instruction, 14(5), 453-467. doi:10.1016/j.learninstruc.2004.06.013

VanLehn, K. (1999). Rule learning events in the acquisition of a complex skill: An evaluation of cascade. The Journal of the Learning Sciences, 8(1), 71-125. doi:10.1207/ s15327809jls0801_3

VanLehn, K., Siler, S., Murray, C., Yamauchi, T. i Baggett, W. B. (2003). Why do only some events cause learning during human tutoring? Cognition and Instruction, 21(3), 209249. doi:10.1207/S1532690XCI2103_01

Verschaffel, L., Luwel, K., Torbeyns, J. i Van Dooren, W. (2009). Conceptualizing, investigating, and enhancing adaptive expertise in elementary mathematics education. European Journal of Psychology of Education, 24(3), 335-359. doi:10.1007/BF 03174765

Vizek Vidović, V. (Ur.) (2005). Cjeloživotno obrazovanje učitelja i nastavnika: Višestruke perspektive. Zagreb: Institut za društvena istraživanja u Zagrebu.

Wang, X. (2013). Why students choose STEM majors: Motivation, high school learning, and postsecondary context of support. American Educational Research Journal, 50(5), 1081-1121. doi:10.3102/0002831213488622

Webb, N. M. (1991). Task-related verbal interaction and mathematics learning in small groups. Journal for Research in Mathematics Education, 22(5), 366-389. doi:10.2307/ 749186

Wineburg, S. (1998). Reading Abraham Lincoln: An expert/expert study in the interpretation of historical texts. Cognitive Science, 22(3), 319-346. doi:10.1207/ s15516709 $\operatorname{cog} 2203 \_3$

Wise, A. F. i O'Neill, K. (2009). Beyond more versus less: A reframing of the debate on instructional guidance. U: S. Tobias i T. M. Duffy (Ur.), Constructivist instruction: Success or failure (str. 82-105). New York: Routledge. 
Ziegler, E. i Stern, E. (2016). Consistent advantages of contrasted comparisons: Algebra learning under direct instruction. Learning and Instruction, 41, 41-51. doi:10.1016/j.learninstruc.2015.09.006

\title{
An Overview of Theoretical Frameworks and Contemporary Approaches for Facilitating Conceptual and Procedural Knowledge in Mathematics
}

\begin{abstract}
Mathematics is one of the key educational areas and the acquisition of mathematical competence has far-reaching effects on individuals' academic and professional development. The basic aspects of mathematical competence are conceptual knowledge, which represents the understanding of concepts, and procedural knowledge, which refers to the application of procedures in order to solve the tasks. Both types of knowledge are important for the development of adaptive expertise and success in mathematics. In order to encourage the acquisition of conceptual and procedural knowledge during education, it is useful to adjust the teaching methods in accordance with the approaches that have shown to be effective through research and practice. Therefore, one aim of this paper would be to present the basic theoretical frameworks of teaching mathematics during the 20th century, as well as two recent teaching approaches, which are rooted in the currently dominant theoretical framework, constructivism: using comparison and productive failure. While using the comparison, students compare one procedure of task solving with the new procedure, and through this comparison, they can detect key features of procedures that also differentiate them. In relation to the sequential procedures presentation, the comparison has been shown to be more effective on the measures of procedural knowledge and flexibility, and conceptual knowledge. Productive failure is based on the integration of guided discovery and direct instruction, and is implemented in two phases: 1) students individually or in the group discover the solutions of tasks; 2) during the instruction provided by teachers, students compare their solutions with the correct solutions, which leads to the discovery and correction of negative knowledge, and the understanding of the basic concepts in the lecture. Despite its positive effects, this approach has been criticized, what is also described in this paper. Based on the presented information, the second aim of the paper would be to suggest guidelines for the practice and future research, in order to increase the number of students who have high levels of mathematical competences, which are important for students' involvement in increasingly demanding STEM professions.
\end{abstract}

Keywords: mathematical competences, conceptual and procedural knowledge, comparison, productive failure 


\title{
Revisión de marcos teóricos y enfoques contemporáneos para el favorecimiento del saber conceptual y procedural en matemáticas
}

\begin{abstract}
Resumen
Las matemáticas son uno de los campos clave de educación, y la adquisición de competencias matemáticas supone efectos a largo plazo sobre el desarrollo académico y profesional de cada individuo. Los aspectos básicos de competencias matemáticas son el saber conceptual, que consiste en entendimiento de conceptos, y el saber procedural, que se refiere a la aplicación de procesos con el fin de resolver una tarea. Los dos tipos de saber son importantes para el desarrollo de la pericia adaptativa y el éxito en matemáticas. Es útil modificar la manera de enseñar de acuerdo con los enfoques que han dado resultados tanto teóricos como prácticos, para estimular la adquisición del saber conceptual y procedural a lo largo del proceso educativo. Por eso, uno de los objetivos de este trabajo fue exponer los marcos teóricos básicos de la enseñanza de matemáticas a lo largo del siglo $\mathrm{XX}$, tanto como dos enfoques recientes que proceden del marco teórico dominante en este momento - el constructivismo, que consiste en la comparación y el fallo productivo. En la comparación, los estudiantes comparan un procedimiento de resolver la tarea con uno nuevo, y a través de esa comparación pueden darse cuenta de las características clave de procedimientos que al mismo tiempo las diferencian. En comparación con la manera secuencial de visualización de procedimientos, el uso de comparación parece ser más efectivo en la adquisición del saber procedural y flexibilidad, tanto como saber conceptual. El fallo productivo se basa en la integración de métodos del descubrimiento guiado y enseñanza frontal, y se lleva a cabo en dos fases: 1) los estudiantes individualmente o en grupos descubren resultados; 2) a través de la enseñanza frontal comparan sus resultados con los resultados correctos, lo que lleva al descubrimiento y corrección del saber negativo, tanto como entendimiento de conceptos básicos de una cierta materia. Aunque tenía efectos positivos, este enfoque recibió varias críticas, que se resumen en este trabajo. A base de informaciones expuestas, otro objetivo de este trabajo fue determinar las directrices para la práctica y para las futuras investigaciones, para aumentar el número de estudiantes con competencias matemáticas desarrolladas, que son importantes para la inclusión de estudiantes en las carreras STEM que están cada vez más exigidas a nivel global.
\end{abstract}

Palabras clave: competencias matemáticas, saber conceptual y procedural, comparación, fallo productivo

Primljeno: 20.12.2017. 


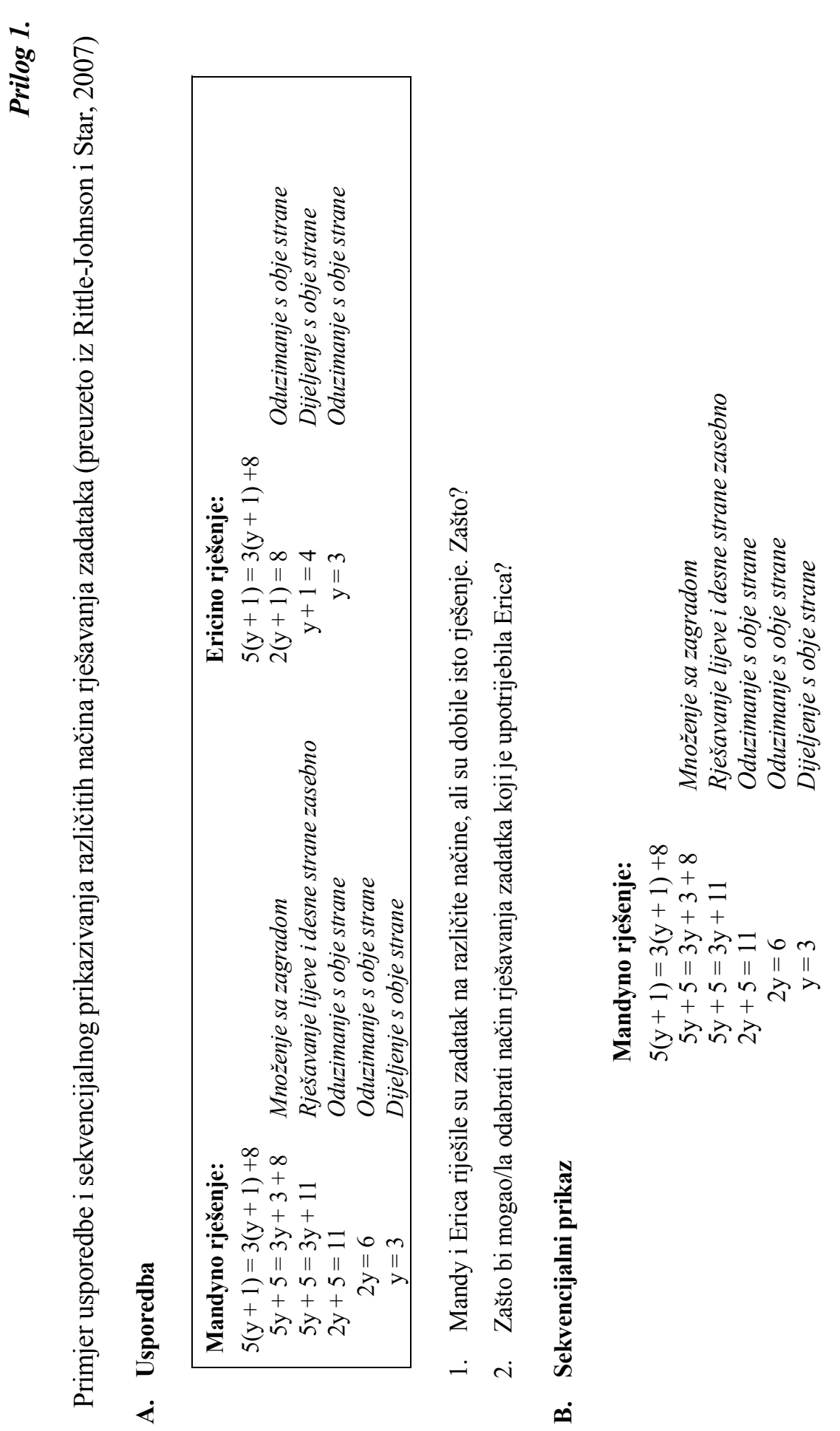




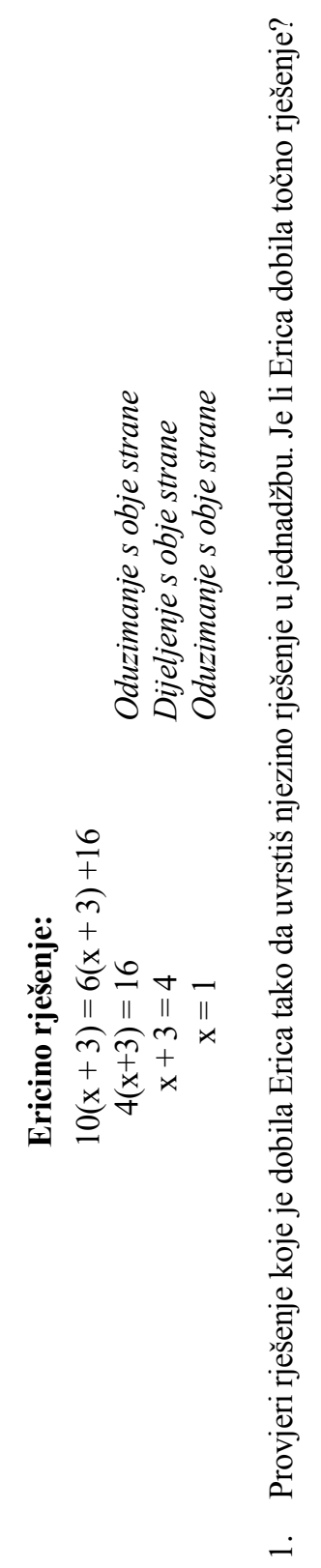

